\title{
Splenic Actinomycosis in a Patient with Chronic Granulomatous Disease: A Case Report and Review of the Literature
}

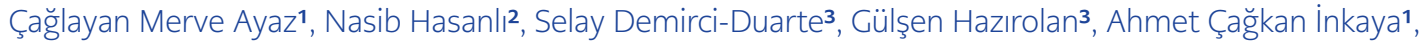 \\ Türkmen Turan Çiftçi ${ }^{4}$ Murat Akova1 \\ 1 Department of Infectious Diseases and Clinical Microbiology, Hacettepe University School of Medicine, Ankara, Turkey \\ 2 Department of Infectious Diseases and Clinical Microbiology, Azerbaijan Medical University, Baku, Azerbaijan \\ 3 Department of Medical Microbiology, Hacettepe University School of Medicine, Ankara, Turkey \\ 4 Department of Radiology, Hacettepe University School of Medicine, Ankara, Turkey
}

\begin{abstract}
Actinomycosis is a granulomatous disease caused by filamentous, gram-positive, anaerobic bacteria. Actinomyces spp. are constituents of the normal flora of mucous membranes. These organisms may cause infection after surgery or damage to the mucosal barrier. Main clinical presentations of actinomycosis are cervicofacial, thoracic, and abdominal forms of the disease. Most cases are caused by Actinomyces israelii, whereas cases due to other Actinomyces spp. are occasionally reported. Actinomycosis is often misdiagnosed because it can mimic other pathological conditions. Besides, Actinomyces spp. are difficult to isolate because they require specific growth conditions. Herein we report a case of splenic actinomycosis caused by Actinomyces naeslundii in a 30-year-old woman with chronic granulomatous disease. Abdominal ultrasound imaging revealed hepatic nodules and splenic abscess; the latter was sampled and cultured. After microbiological diagnosis, she received intravenous (IV) penicillin followed by long-term oral amoxicillin-clavulanate. Abscesses regressed with drainage and prolonged antibiotic therapy. The patient was followed-up for six months without any symptoms. Splenic actinomycosis is a rare disease but should be considered in the differential diagnosis of splenic abscesses in patients with chronic granulomatous disease.
\end{abstract}

Keywords: Actinomyces, Actinomyces naeslundii, Splenic actinomycosis

\section{INTRODUCTION}

A ctinomycosis, a chronic granulomatous condition, is caused by Actinomyces spp. a gram-positive anaerobic bacterium. Actinomyces spp. usually inhabit oral, gastrointestinal and female genital tract $(1,2)$. The disease commonly manifests as slowly progressive cervicofacial (50\% of cases), thoracic and pulmonary (15-20\%) or abdominopelvic (about 20\% ) infection (3).

Immunosuppression due to prolonged corticosteroid use, chemotherapy, human immunodeficiency virus infection, lung and renal transplantation have been reported as
Corresponding Author: Çağlayan Merve Ayaz

E-mail: merve.ayz@hotmail.com

Received: December 04, 2019 Accepted: December 09, 2019 Published: December 25, 2019

\section{Suggested citation:}

Ayaz ÇM, Hasanlı N, DemirciDuarte S, Hazırolan G, İnkaya AÇ, Çiftçi TT et al. Splenic actinomycosis in a patient with chronic granulomatous disease: a case report and review of the literature. Infect Dis Clin Microbiol 2019; 3: 158-164.

DOI: $10.36519 /$ idcm.2019.19028 


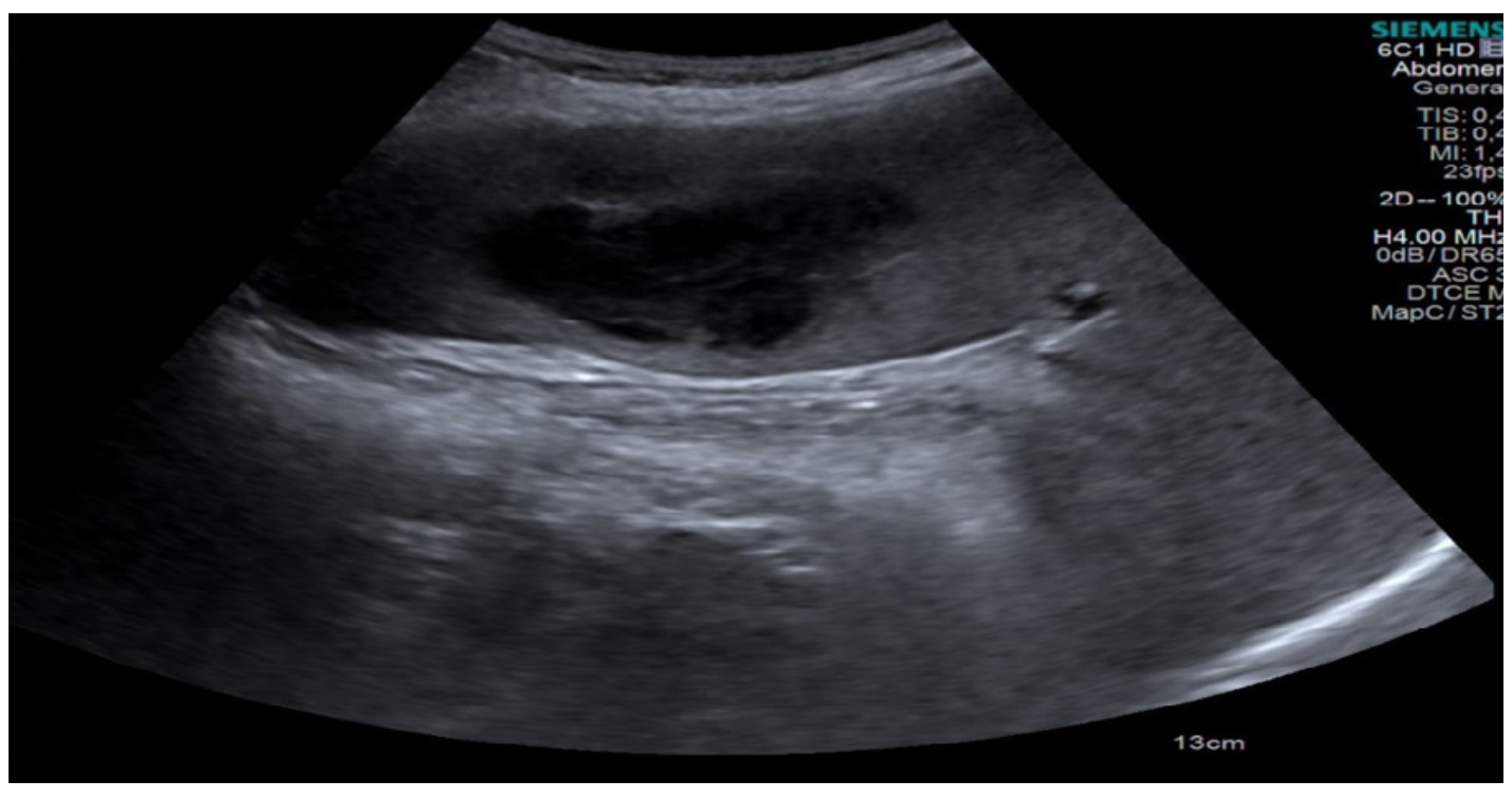

Figure 1. Ultrasonograpy showing a heterogeneous abscess with hypoechoic center in spleen.

predisposing factors. Age, male gender, poor oral hygiene, diabetes mellitus, alcoholism, local tissue damage caused by trauma, recent surgery, irradiation and intrauterine devices are other risk factors for actinomycosis (3).

Chronic granulomatous disease (CGD) is an inherited primary immunodeficiency caused by functional impairment of NADPH oxidase complex in neutrophilic granulocytes and monocytes and characterized by recurrent and severe catalase-positive bacterial and fungal infections, dysregulated inflammation, and autoimmunity (4).

Here we present an uncommon case of hepatosplenic actinomycosis caused by Actinomyces naeslundii in a patient with CGD.

\section{CASE PRESENTATION}

A 30-year-old female patient diagnosed with CGD for 25 years was admitted to the emergency department for having a 3-month history of abdominal pain and left upper quadrant tenderness. She had a history of surgery (cesarean section) which complicated by concomitant intraabdominal infections including cervical, intrauterine, liver abscesses in 2016. After surgery and surgery-related complica- tions, she stopped using prophylactic antibacterial (trimethoprim-sulfamethoxazole) and antifungal (itraconazole) therapies for CGD. She had used these prophylactic drugs intermittently almost the past ten years. Physical examination revealed that body temperature was $37^{\circ} \mathrm{C}$, blood pressure was $110 / 70 \mathrm{~mm} / \mathrm{Hg}$, respiratory rate was $15 / \mathrm{min}$ and saturation was $95 \%$ with hepatosplenomegaly. Laboratory investigations showed a normal complete blood count with typical leukocyte formula, normal biochemistry panel, negative serology for

\section{HIGHLIGHTS}

- Splenic actinomycosis is a rare disease and should be suspected in immunocompromised patients with splenic abscess.

- Diagnosis can be challenging because of the non-specific mass with abscess mimicking malignancy and other chronic diseases.

- Bacterial cultures remain sterile in more than $50 \%$ of cases.

- Majority of cases are diagnosed with the presence of characteristic sulfur granules in the specimen and detailed histopathological examination. 

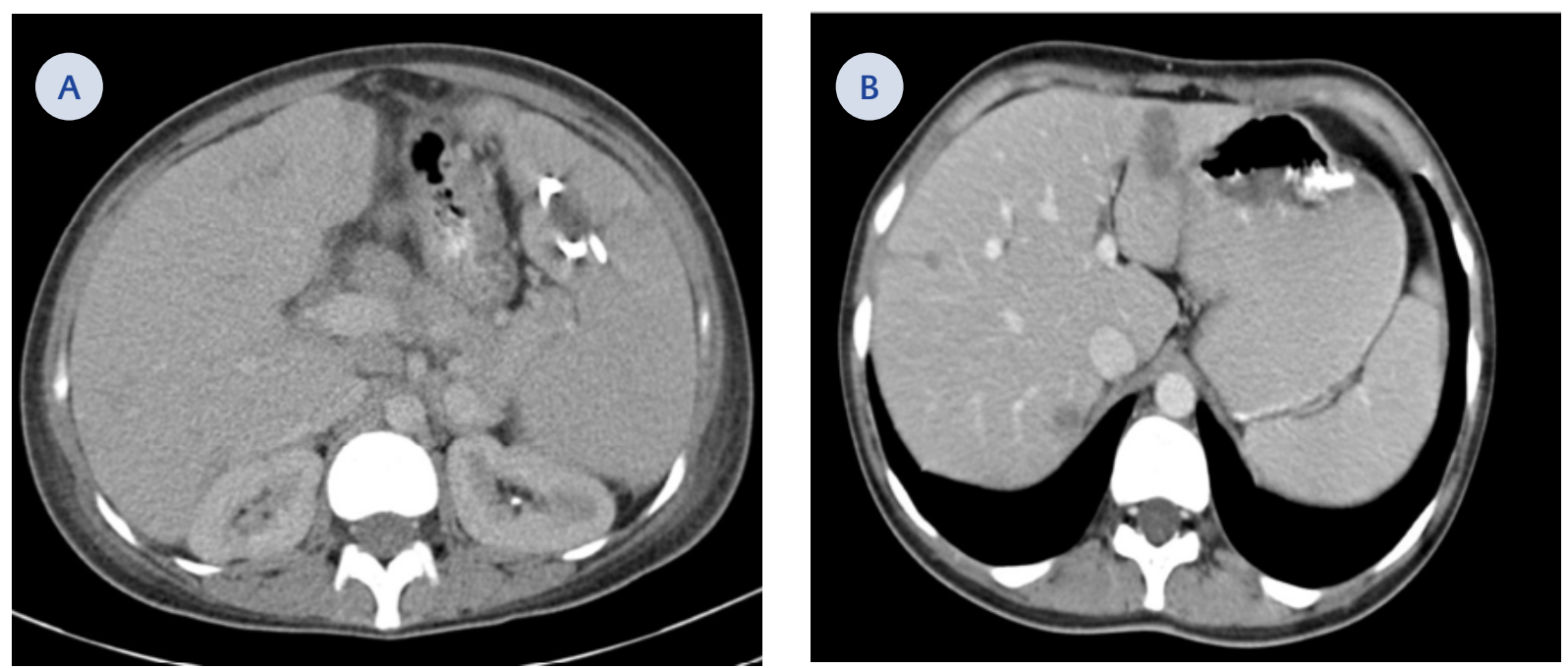

Figure 2. Follow up-scan at the 3rd week of parenteral therapy showing regression of splenic abscess (A) and decreased number of lesions in liver (B).

HIV, HBV and HCV but $14.3 \mathrm{mg} / \mathrm{dL}$ C-reactive protein (normal range: 0-0.8 mg/dL).

Abdominal ultrasonography identified a heterogeneous $60 \times 45 \mathrm{~mm}$ abscess with a hypoechoic centre in an enlarged spleen and multiple small cystic lesions in the liver (Figure 1). Splenic abscess drained through a needle aspiration with temporary drainage catheter and several samples collected for microbiological examination; however, no sample was available for histopathological evaluation. Then, piperacillin-tazobactam $4.5 \mathrm{~g}$ every 6 hours was given empirically.

Gram staining of the drainage material showed gram-positive filamentous branching bacilli. The sample was cultured on Columbia agar supplemented with $5 \%$ sheep's blood, chocolate agar supplemented with vitox, eosin methylene blue agar and thioglycollate broth and incubated at $35^{\circ} \mathrm{C}$ in $5 \% \mathrm{CO}_{2}$. After three days of incubation, we observed white non-hemolytic dry colonies on only Columbia agar which was incubated in an anaerobic atmosphere. Gram staining of these colonies revealed the presence of gram-positive microorganisms whose morphology resembled that of the previously described filamentous bacilli. Catalase test was performed with $15 \% \mathrm{H}_{2} \mathrm{O}_{2}$ and found negative. The cultured bacterial colonies were identified as Actinomyces naeslundii by MALDI-TOF. After identification, the sample was cultured on buffered char- coal yeast extract agar for a final confirmation, and the colonies were again confirmed by MALDI-TOF as Actinomyces naeslundii. No hepatic nodules were sampled, and it was assumed that the same bacteria also caused liver lesions.

Upon microbiological diagnosis, antimicrobial therapy was switched to 20 million/unit penicillin G given as a 24-hour continuous infusion. Abdominal computerized tomography (CT) performed on the 3rd week of parenteral therapy which revealed complete regression of splenic abscess with drainage catheter and decreased the number of lesions in the liver (Figure 2). Penicillin G treatment was continued for four weeks, meanwhile abdominal pain and left upper quadrant tenderness of patient dissolved completely. The patient was discharged with oral amoxicillin-clavulanate 1000 mg every eight hours.

Two months after discharge, the patient remained symptom-free and with the total disappearance of splenic and liver lesions. Oral antibiotic therapy was prolonged to six months in total. Prophylactic antibiotic (trimethoprim-sulfamethoxazole) treatment for chronic granulomatous disease had been resumed with the treatment of hepatosplenic actinomycosis. Long-term prophylaxis for actinomycosis was not given as no further lesions were detected in a follow-up abdominal taken at six months and one year. 
Table 1. Summary of published cases of splenic and hepatosplenic actinomycosis.

\begin{tabular}{|c|c|c|c|c|c|c|c|c|}
\hline Reference & $\begin{array}{l}\text { Age/ } \\
\text { Gender }\end{array}$ & $\begin{array}{l}\text { Co-morbid } \\
\text { conditions }\end{array}$ & $\begin{array}{l}\text { Biopsy } \\
\text { confirmed }\end{array}$ & $\begin{array}{l}\text { Culture } \\
\text { Report }\end{array}$ & $\begin{array}{l}\text { Presenting } \\
\text { symptoms }\end{array}$ & $\begin{array}{l}\text { Lesion size } \\
\text { in spleen }\end{array}$ & $\begin{array}{l}\text { Treatment/ } \\
\text { Duration of } \\
\text { Antimicrobial }\end{array}$ & Outcome \\
\hline $\begin{array}{l}\text { Lisa- Garcia M et al., } \\
2017(7)\end{array}$ & unsp. & unsp. & unsp. & unsp. & unsp. & unsp. & $\begin{array}{l}\text { Splenectomy } \\
\text { unsp. }\end{array}$ & Cured \\
\hline $\begin{array}{l}\text { Kim SY et al., } \\
2014(11)\end{array}$ & 50/female & $\begin{array}{l}\text { Intrauterin } \\
\text { device }\end{array}$ & Yes & Negative & $\begin{array}{l}\text { Fever, } \\
\text { abdominal } \\
\text { pain }\end{array}$ & $\begin{array}{l}\text { Multiple } \\
\text { abscesses in } \\
\text { spleen }\end{array}$ & $\begin{array}{l}\text { Splenectomy } \\
\text { Oral penicillin, } 3 \\
\text { months }\end{array}$ & Cured \\
\hline $\begin{array}{l}\text { Lo TE et al., } \\
2014(10)\end{array}$ & 24/female & - & Yes & - & $\begin{array}{l}\text { Abdominal } \\
\text { enlargment, } \\
\text { ascites }\end{array}$ & $\begin{array}{l}\text { Multiple } \\
\text { abscesses in } \\
\text { spleen }\end{array}$ & $\begin{array}{l}\text { Needle aspiration } \\
\text { Amoxicillin, } 24 \text { months }\end{array}$ & Cured \\
\hline $\begin{array}{l}\text { Wang HK et al., } \\
\text { 2012(16) }\end{array}$ & $37 /$ male & - & Yes & Negative & $\begin{array}{l}\text { Fever, } \\
\text { abdominal } \\
\text { pain }\end{array}$ & $\begin{array}{l}6 \times 5 \mathrm{~cm} \text { and } \\
\text { multiple liver } \\
\text { nodules }\end{array}$ & $\begin{array}{l}\text { Splenectomy } \\
\text { Penicillin-G, } 4 \text { months }\end{array}$ & Cured \\
\hline $\begin{array}{l}\text { Sinhasan SP, } \\
\text { 2011(8) }\end{array}$ & 52/female & - & Yes & Negative & $\begin{array}{l}\text { Abdominal } \\
\text { pain }\end{array}$ & $\begin{array}{l}\text { Two } \\
\text { abscesses } \\
\text { ( } 2 \text { and } 3 \mathrm{~cm} \\
\text { in diameter) }\end{array}$ & $\begin{array}{l}\text { Drainage failure, } \\
\text { splenectomy } \\
\text { Treatment with u } \\
\text { unsp. antibiotic }\end{array}$ & Cured \\
\hline F.I. Jabr, 2006(12) & 72/female & $\begin{array}{l}\text { Diabetes } \\
\text { type } 2\end{array}$ & Yes & Negative & $\begin{array}{l}\text { Fever, } \\
\text { abdominal } \\
\text { pain, chills }\end{array}$ & $\begin{array}{l}\text { Multiple } \\
\text { abscesses }\end{array}$ & $\begin{array}{l}\text { Splenectomy } \\
\text { Penicillin-G, } 6 \text { months }\end{array}$ & Cured \\
\hline $\begin{array}{l}\text { N. Azarpira et al., } \\
2005(17)\end{array}$ & $12 /$ male & - & Yes & unsp. & $\begin{array}{l}\text { Anorexia, } \\
\text { abdominal } \\
\text { pain, fever }\end{array}$ & unspecified & $\begin{array}{l}\text { Splenectomy } \\
\text { Penicillin-G, unsp. } \\
\text { duration }\end{array}$ & Cured \\
\hline $\begin{array}{l}\text { C.Y. Chen et al., } \\
2002(18)\end{array}$ & 47/male & $\begin{array}{l}\text { Acute } \\
\text { myeloid } \\
\text { leukemia } \\
\text { (AML) }\end{array}$ & Yes & Negative & $\begin{array}{l}\text { Upper } \\
\text { quadrant } \\
\text { tenderness }\end{array}$ & $\begin{array}{l}2 \mathrm{~cm} \text { in } \\
\text { diameter }\end{array}$ & $\begin{array}{l}\text { Splenectomy } \\
\text { Amoxicillin/clavulanic } \\
\text { acid, } 6 \text { months }\end{array}$ & $\begin{array}{l}\text { Died of } \\
\text { AML }\end{array}$ \\
\hline $\begin{array}{l}\text { E. Garduño et al., } \\
2000(19)\end{array}$ & 14/female & $\begin{array}{l}\text { Autoimmune } \\
\text { hepatitis, } \\
\text { endocarditis }\end{array}$ & None & $\begin{array}{l}\text { Actinomyces } \\
\text { meyeri }\end{array}$ & $\begin{array}{l}\text { Fever, } \\
\text { abdominal } \\
\text { pain, } \\
\text { diarrhea, } \\
\text { nause }\end{array}$ & $\begin{array}{l}4.4 \times 2.6 \mathrm{~cm} \\
1.4 \times 1.4 \mathrm{~cm}\end{array}$ & $\begin{array}{l}\text { Needle aspiration } \\
\text { Imipenem/cilastatin, } \\
58 \text { days }\end{array}$ & Cured \\
\hline $\begin{array}{l}\text { P.M.Chan et al., } \\
1999(20)\end{array}$ & 69/male & - & Yes & Negative & $\begin{array}{l}\text { Fever, } \\
\text { abdominal } \\
\text { pain }\end{array}$ & $\begin{array}{l}6 \mathrm{~cm} \text { in } \\
\text { diameter }\end{array}$ & $\begin{array}{l}\text { Splenectomy } \\
\text { Penicillin-G, } 3 \text { months }\end{array}$ & Cured \\
\hline $\begin{array}{l}\text { A.I. Quinter-Del-Rio } \\
\text { et al., } 1997 \text { (21) }\end{array}$ & $\begin{array}{l}18 \text { months/ } \\
\text { female }\end{array}$ & - & Yes & $\begin{array}{l}\text { Actinomyces } \\
\text { naeslundii }\end{array}$ & $\begin{array}{l}\text { Fever, } \\
\text { swelling } \\
\text { finger and } \\
\text { toe }\end{array}$ & $5 \times 5 \mathrm{~cm}$ & $\begin{array}{l}\text { Drainage failure, } \\
\text { splenectomy } \\
\text { Penicillin-G, } 6 \text { months }\end{array}$ & Cured \\
\hline $\begin{array}{l}\text { R.L.Sperling et al., } \\
1967(22)\end{array}$ & 40/male & Alcoholism & Yes & Negative & $\begin{array}{l}\text { Abdominal } \\
\text { pain, } \\
\text { anorexia }\end{array}$ & $\begin{array}{l}\text { Splenic } \\
\text { rupture }\end{array}$ & $\begin{array}{l}\text { Splenectomy } \\
\text { Penicillin-G, } 2 \text { weeks }\end{array}$ & Cured \\
\hline $\begin{array}{l}\text { Hing C. Ng. L. et al., } \\
2019 \text { (23) }\end{array}$ & 37/female & $\begin{array}{l}\text { Hepatitis C, } \\
\text { Intrauterin } \\
\text { device, IV } \\
\text { drug abuse }\end{array}$ & Yes & $\begin{array}{l}\text { Actinomyces } \\
\text { europaeus }\end{array}$ & $\begin{array}{l}\text { Fever, } \\
\text { abdominal } \\
\text { pain }\end{array}$ & unsp. & $\begin{array}{l}\text { Splenectomy } \\
\text { unsp. }\end{array}$ & Cured \\
\hline
\end{tabular}

Note: unsp. abbreviation of unspecified. 


\section{DISCUSSION}

Actinomyces are a part of normal gut microbiota, but cannot penetrate healthy skin or mucous membranes and have low pathogenicity. Mucosal barrier damage is mandatory for actinomycosis infection. However, once invasive infection ensues, it causes fistulas, sinuses, and may appear as abscess and abdominal mass which can often be mistaken for a neoplasm (5).

Actinomyces is an important catalase-negative microorganism to be considered in CGD patients. There is an unusual and unexpected predisposition to poor pathogenic Actinomyces species in CGD patients. Actinomycosis should be investigated and treated immediately in these patients with extensive and long-term clinical symptoms (6).

Most common sites of actinomycosis are cervicofacial (\%50), abdominopelvic (\%10-20) and respiratory tract (\%10-20) (3). Actinomycosis may mimic many diseases because it can occur in various anatomical areas. Therefore, it should be kept in mind that it may present with bloodstream infections, infective endocarditis, osteomyelitis, central nervous system infections (such as meningitis, meningoencephalitis, brain abscess), cutaneous infections and organ-specific symptoms (1).

Actinomycosis is a rare cause of intra-abdominal infection. Primary risk factors associated with this condition are loss of integrity of gastrointestinal mucosa (via trauma or infection), previous abdominal surgery, intra-abdominal infection, gastrointestinal foreign body and immunosuppression (3). Our patient had a history of abdominal surgery and an immunosuppressive condition caused by CGD, both of which possibly were main predisposing factors for the abscess in spleen and liver nodules.

Splenic lesions due to an actinomycotic infection are exceptional. We have reviewed PubMed, Scopus, Web of Science and Google Scholar from 1967 to November 2019 in the English-language literature. The keywords used for the search were abdominal actinomycosis, splenic actinomycosis, splenic abscess and actinomycosis. Twelve cases of splenic actinomycosis were identified as of writing this paper. Table 1 summarizes these patients, including 10 cases of primary splenic actinomycosis, one patient with hepatosplenic involvement, one patient with splenic abscess following splenic artery embolization and another one with abdominal actinomycosis complicated with splenic abscess. All age groups (range 18 months to 72) were affected with no gender predilection (five males and seven females, gender not specified in one case). Among 13 patients, six have co-morbid situations and predisposing factors such as leukaemia, diabetes mellitus, alcoholism, IV drug use, hepatitis C, autoimmune disease and intrauterine device. Majority of patients with splenic actinomycosis presented with abdominal pain and fever (Table 1).

Diagnosis of splenic actinomycosis can be challenging because of the non-specific mass with abscess mimicking malignancy and other chronic diseases such as granulomatous infections. A definitive diagnosis of splenic actinomycosis requires to isolate Actinomyces spp. in culture. Bacterial cultures in anaerobic conditions are necessary for identification, but the culture remains sterile in more than 50\% of cases (7). Majority of cases were diagnosed with the presence of characteristic sulfur granules in the specimen and detailed histopathological examination (8). In our case, Actinomyces naeslundii was isolated from culture, but the histopathological examination was not performed from the splenic aspirate. Nor we sampled the hepatic lesions, but given the fact that they disappeared with antibiotic therapy, we assumed that the hepatic nodules were also due to actinomycosis.

Radiological techniques are inadequate for diagnosis of abdominal actinomycosis, except for CT scan, which shows anatomical location, the content of lesions, their relation to adjacent tissues and effectiveness of treatment (9). Infiltrative irregular hypodense lesions were more frequently found by CT scan with contrast enhancement $(10,11)$.

Upon reviewing the literature, we found that the usual therapeutic approach to actinomycotic abscesses in the spleen was splenectomy with longterm antibiotic treatment. The reason for this preference is to avoid a high mortality rate such as splenic rupture, clinical failure under long-term an- 
tibiotics alone and difficulty in diagnosis in patients $(11,12)$. Percutaneous drainage of a splenic abscess has been considered as an effective alternative way and less invasive treatment method than surgical intervention in selected patients (13). In our case, we preferred percutaneous drainage of abscess followed by prolonged antibiotic treatment, because the abscess was so close to the splenic capsule thus, suitable for percutaneous drainage.

Reports on in vitro antimicrobial susceptibility testing for Actinomyces strains are rare, and there is very little data available in the literature. Carbapenems, various beta-lactam antibiotics, tetracyclines, erythromycin and clindamycin, have been used for treatment $(14,15)$. Splenectomy and high-dose intravenous penicillin (10-20 million units per day) are recommended for treatment of splenic actinomycosis. A 4-8 week course parenteral penicillin followed by oral penicillin for another 4-8 weeks should be adequate, but long course treatment may be necessary for slowly responding patients (16). Treatment for immunocompetent patients treatment is usually straightforward but could be more complicated in patients with CGD because of delayed diagnosis, non-specific symptoms and increased risk of chronic invasive or debilitating disease (6). Our patient recovered totally under antibiotics and now followed-up regularly at our outpatient clinic.

In conclusion, although splenic actinomycosis is a rare disease, it should be suspected in immunocompromised patients with splenic abscess(es). Diagnosis is made by culture and histopathological examination. Prolonged penicillin therapy preceded by drainage can be the organ-preserving treatment.
Peer-review: Externally peer-reviewed

Author Contributions: Concept - C.M.A., A.C.I., M.A.; Design - A.C.I., M.A., N.H., C.M.A.; Supervision - C.M.A., N.H., S.D.D.; Materials S.D.D., G.H., T.T.C.; Data Collection and/or Processing - C.M.A., N.H., S.D.D., G.H., T.T.C.; Analysis and/or Interpretation - C.M.A., A.C.I., M.A.; Literature Review - C.M.A., N.H., M.A., A.C.I.; Writer - C.M.A., N.H., A.C.I., M.A., S.D.D., G.H., T.T.C.; Critical Reviews C.M.A., N.H., A.C.I., M.A., S.D.D., G.H., T.T.C.
Conflict of Interest: The authors have no conflict of interest to declare.

Acknowledgements: We would like to thank to the members of SCARE (Study group for Carbapenem Resistance) for their encouragements and supports.

Financial Disclosure: The authors declared that this study has received no financial support.

\section{REFERENCES}

1 Valour F, Senechal A, Dupieux C, Karsenty J, Lustig S, Breton P, et al. Actinomycosis: etiology, clinical features, diagnosis, treatment, and management. Infect Drug Resist 2014; 7: 18397.

2 Acar B, Caglayan F, Inkaya AC, Kurtulan O. Actinomyces-associated lesions located in the gingiva: case report of rare gingival lesions. Contemp Clin Dent 2017; 8: 182-4.

3 Wong VK, Turmezei TD, Weston VC. Actinomycosis. BMJ 2011; 343: d6099.

4 Arnold DE, Heimall JR. A Review of Chronic Granulomatous Disease. Adv Ther 2017; 34: 2543-57.

5 Cintron JR, Del Pino A, Duarte B, Wood D. Abdominal actinomycosis. Dis Colon Rectum 1996; 39: 105-8.

6 Reichenbach J, Lopatin U, Mahlaoui N, Beovic B, Siler U, Zbinden R, et al. Actinomyces in chronic granulomatous disease: an emerging and unanticipated pathogen. Clin Infect Dis 2009; 49: 1703-10.
7 Lisa-Gracia M, Martín-Rivas B, Pajarón-Guerrero M, ArnáizGarcía A. Abdominal actinomycosis in the last 10 years and risk factors for appendiceal actinomycosis: review of the literature. Turk J Med Sci 2017; 47: 98-102.

8 Sinhasan SP. Actinomycotic splenic abscess: a rare case report. Indian J Pathol Microbiol 2011; 54: 638-9.

9 Huang CJ, Huang TJ, Hsieh JS. Pseudo-colonic carcinoma caused by abdominal actinomycosis: report of two cases. Int J Colorectal Dis 2004; 19: 283-6.

10 Lo TEN, Berba RP. Splenic Actinomycosis Mimicking Malignant Lymphoma-A Rare Case of Abdominal Actinomycosis. Phil J Int Med 2014; 52: 1-4.

11 Kim SY, Lee SK, Moon SB. Abdominal actinomycosis complicated by delayed splenic abscess. Surg Infect (Larchmt) 2014; 15: $662-4$.

12 Jabr FI, Skeik N. Splenic abscess caused by actinomycosis. Intern Med 2007; 46: 1943-4. 
13 Murray AW, Macgregor AB. A case of multiple splenic abscesses managed non-operatively. J R Coll Surg Edinb 2000; 45: 189-91.

14 Hansen JM, Fjeldsøe-Nielsen H, Sulim S, Kemp M, Christensen JJ. Actinomyces species: A danish survey on human infections and microbiological characteristics. Open Microbiol J 2009; 3: 113-20.

15 Steininger C, Willinger B. Resistance patterns in clinical isolates of pathogenic Actinomyces species. J Antimicrob Chemother 2016; 71: 422-7.

16 Wang HK, Sheng WH, Hung CC, Chen YC, Liew PL, Hsiao CH, et al. Hepatosplenic actinomycosis in an immunocompetent patient. J Formos Med Assoc 2012; 111: 228-31.

17 Azarpira N, Ghasemzadeh. Splenic actinomycosis: unusual presentation. Iran J Med Sci 2015; 30: 141-3.

18 Chen CY, Chen YC, Tang JL, Lin WC, Su IJ, Tien HF. Splenic actinomycotic abscess in a patient with acute myeloid leukemia. Ann Hematol 2002; 81: 532-4.
19 Garduño E, Rebollo M, Asencio MA, Carro J, Pascasio JM, Blanco J. Splenic abscesses caused by Actinomyces meyeri in a patient with autoimmune hepatitis. Diagn Microbiol Infect Dis 2000; 37: $213-4$

20 Chan PM, Chong SM, Ng BK, Chan ST. Splenic actinomycosis. J R Coll Surg Edinb 1999; 44: 344

21 Quintero-Del-Rio AI, Trujillo M, Fink CW. Actinomycotic splenic abscesses presenting with arthritis. Clin Exp Rheumatol 1997; 15: 445-8.

22 Sperling RL, Heredia R, Gillesby WJ, Chomet B. Rupture of the spleen secondary to actinomycosis. Arch Surg 1967; 94: 344-8.

$23 \mathrm{Ng}$ Liet Hing C, Wullschleger M, Patel B. Actinomycosis of the spleen following splenic artery embolization in the setting of trauma. ANZ J Surg 2019. doi: 10.1111/ans.15601 